\title{
Local Notion of Child Labour in Akwa Ibom State, Nigeria
}

\author{
${ }^{1}$ Supper Roland Okijie, ${ }^{2}$ Victor Effiong Ben \\ ${ }^{I}$ Department of Sociology/Anthropology, University of Uyo, Uyo. \\ ${ }^{2}$ Department of Sociology/Anthropology,University of Uyo, Uyo.
}

\begin{abstract}
Current interest in the study of child labour has rejuvenated copious attention demanding for a better socio-economic deal for the children of Nigeria, and Akwa Ibom State in particular. This interest has not paid sufficient attention to the perceptions or notions of the local inhabitants, leading to the undermining of local beliefs and practices very crucial and fundamental to understanding and managing child labour. This paper examines traditional beliefs associated with child labour in Akwa Ibom State, Nigeria. The paper builds on data sought and obtained from observations, interviews and focus group discussions. Findings in the study indicate that behaviours, attitudes and knowledge are fairly linked to tradition, and are key factors in dealing with child labour. The paper concludes by making a number of recommendations.
\end{abstract}

\section{Introduction}

For some time the issue of child labour has raised serious concern in Nigeria because of its negative impacts on the lives and future of children. These concerns have provoked quite a number of studies ( Clark and Yusufu, 2012; Mitullah, 2004; Oloko, 1990), but without consideration of the perception of people in the rural areas. Yet some forms of traditional beliefs and practices cannot be discarded or simply waived aside. Knowledge on how child labour is understood and constructed in local communities has the capacity to broaden our understanding of the menace, as well as suggest direction for current efforts on child labour eradication. Scholars (Bhalotra and Heady, 1998; Canagarajah and Coulombe, 1998) have demonstrated the importance of traditions and beliefs in understanding child labour. Belief is very instrumental in understanding and directing the actions of people. Beliefs are crucial to the formation of attitude and opinion, and as cultural elements, they determine conception of the world, mental power, cosmology and customary practices of a people (Ottong et al, 1994). In Nigeria, anecdotal evidence suggests that traditional beliefs are compelling factors in the understanding of child labour. However, scholarly investigations or insights into these issues have been scant, and scholars are yet to exploit these challenges. This study is based on the belief that gaining insights into these issues will carve out opportunities that are most crucial to effective child labour eradication programme.

This study is significant for two reasons. First, it will provide insights into the traditional notions of child labour among the people. Second, the study has implications for directing and guiding child labour regulation in Nigeria.

\section{Conceptual Framework}

The term child labour connotes "work performed by children who are too young for the task in the sense that by performing it they unduly reduce their present economic welfare or their future income earning capabilities, either by shrinking their future external choice sets or by reducing their own future individual productive capabilities" (Andvig, 2001). According to Oloko (1990), it means the exploitative children's work which violates the right of children to conditions and resources which would ensure that they maintain a healthy and normal development in significant aspects of their lives. Child labour is both disgusting and dehumanizing. This is because young boys and girls are constantly exposed to socio-economic activities far beyond their ages and abilities, with little or no consideration for their future wellbeing. It is particularly dangerous since it involves sacrificing a child's future welfare in exchange for immediate benefit (Udry, 2003).

It is estimated that there were 80 million children between the ages of 10-14, who undertook long and difficult work so much so that it constrained normal development (UNICEF, 1991). In Sub-Saharan Africa the incidence of child labour is so high with 49 million children economically active (ILO, 2006). The situation is not different in Nigeria particularly in Akwa Ibom State which for decades has been a storehouse for shopping for housemaids and labourers for the Yorubas and Binis. Recent data shows that about 26 percent of children between the ages of 10-14 in Nigeria are engaged in economic activities (ILO, 1995). The magnitude of children actively involved in economic activity in Nigeria not only indicates how gloomy and pathetic the situation is, but also provokes the need for proper understanding of the problem with a view to tackling it.

The global issue of child labour is associated with several factors which are well documented in the literature. Parents engage in child labour not because they like it but are motivated by the need to survive ( Basu 
and Van, 1998). Baland and Robinson (2000) reveal that commitment hitch between parents and children may necessitate child labour. Furthermore, the rapid growth in population of many less developed countries, high unemployment rate, low wages and inflation have contributed to the engagement of children in economic activity (Bass, 2004; Lopez-Calva, 2001). In Nigeria the above factors hold sway and appear to be increasing by the day. Among the Ibibio, the philosophy is promoted by the adage; "owo odung owo okpon" which means a person lives, grows and becomes wealth in another person's (master or mistress hands. Consequently our towns and villages are inundated with children who are engaged in one economic activity or the other. Such economic activity includes, but not limited to street hawking, hustling, prostitution and engagement as domestic servants or housemaids. Often times the children are forced to work day and night without minding the implications of the tasks on their wellbeing and development. The worst is for children with no parent (orphans) and those with only one parent who marry another.

Scholars (Aderinto, 2000; Singh, 1999; Weiner, 1991) have also documented the consequences of child labour. These consequences affect the finance, leisure, health, education and social wellbeing of a child. This raises questions bordering on the future development and wellbeing of children given that their present lives are constantly abused by parents and or guardian. Children who manage to run away from their houses are constantly exposed to dangers partly as they run into wicked masters or mistress and partly as they become vulnerable to environmental elements such as bad weather, wild animal, armed robbers and child molesters.

In Akwa Ibom State, the belief and attitude of the people towards child labour is partly hinged on the conception that children are sources of wealth. This notion induces a master-servant relationship whereby children are exploited continuously in a bid to meet the needs of the family, especially in the area of income. In this case children find it difficult to resist being engaged in economic activity because they are powerless. Parents do not really care about what happens to their wellbeing as long as life goes on.

\section{Method}

The study was conducted in three local governments areas, each drawn from each senatorial districts of Akwa Ibom State. The study areas were chosen to reflect the unique characteristics of the various ethnic nationalities in the state. The three local government areas include Ikono, Mbo and Etim Ekpo. These local government areas cannot boast of basic social amenities compared to some others in the state. Good roads, hospitals and improved recreational facilities were conspicuously unavailable except in the headquarters of their respective councils. Most inhabitants in these councils show signs of being poor; not having the basic necessities of life. Few available schools are in a serious state of disrepair, and in dire need of facilities for effective learning to take place.

The study relies on data collected from respondents in the six communities selected from the three local government areas chosen. These participants were recruited through a multistage sampling technique which initially involved the use of table of random number to select two villages from each of the three local government areas. The villages selected include: Itak Ikot Akpandem; Nung Ukim (Ikono); Uko-Akpan; Eyoukut Ewang (Mbo); Iwukem; Ikot Esop (Etim Ekpo). The use of table of random number was necessary due to the similarities in cultural background of the ethnic nationalities found in the three local government areas. The second stage involved the grouping of households into clusters and systematically selecting participants after every three households in such a manner that not more than two participants came from a household. Altogether, 600 respondents were recruited for the study. Equal numbers of respondents were surveyed from each village.

Determined not to allow language and ethnic differences between the researchers and the participants obstruct the quality of the data gathered, the researcher employed the services of three Ibibio speaking research assistants recruited from the researchers' colleagues in the Faculty of Social Sciences, University of Uyo. The research assistants had sufficient knowledge in the techniques and ethics of data collection. The knowledge that the research assistants were of the same cultural background with the participants boosted the co-operation that existed during the period of investigation, as participants willingly volunteered information that were considered sensitive.

In all, twelve focus group sessions were carried out - two in each village. Each focus group comprised men, women and community elders. The focus group discussion furnished the researchers the chances of gaining insights into the shared understanding of the issues under investigation. Personal interviews were held with few children who for convenience reason were not allowed to partake in the group discussion. The researchers sought for the consent of the participants before their responses were recorded using audiotape recorder, after assuring them of the strictest confidentiality of whatever information they would volunteer.

The audiotapes from both individual and group interviews were later translated into English with the assistance of the three Ibibio speaking research assistants. The data gathered were expected to broaden our understanding of traditional notion of child labour and suggest directions for current efforts to promote child welfare in society. 


\section{Notion Of Child Labour}

Emanating from the discussions about child labour and its meanings is the belief that children are sources of wealth. 'Children are bound to engage in economic activities to ensure the survival of the family' declared one respondents aged 62. 'It is inconceivable to have children and still die of hunger' says yet another 43-year-old respondent (a woman). Similarly, a 47-year-old-man posited:

I don't understand...All I know is that my children must continue to work hard so that we can collectively overcome poverty in our family.

Another 58-year-old man said:

I am happy because, with my children being strong and happy to work, poverty will not kill me. My children, although very young, are assisting me to meet daily needs of our family.

Children are even socialized into accepting this notion. A child who was self identified as a 10- year old girl posited behind her parents; "I am forced to engage in street hawking even till dusk because my parents who are poor told me that God sent me to alleviate their burden. Look at me, at my age I am already tired and weary." Another added "My parents' feel I should be the one to take care of them notwithstanding my tender age." An exploration of their narratives reveals that children are subjected to challenging socio-economic activities to boost family income without minding the effects of such activities on their wellbeing.

Another notion opined by the participants centres on the belief that women are seen but not heard. Few parents tend to favour boys to the detriment of girls. The deplorable state of the female child can be well appreciated in the submission of a 46 year-old-man: 'I cannot spend my resources to train my daughters only for them to get married and better the lives of their husbands while I suffer. Let them stay at home and work.' Similarly, a 39 year-old-man had this to say:

Female children are better off working in the farm or as housemaids to rich families. Why would I leave the boys and concentrate on them. Female children must be trained well so that when married, they would satisfy their marital homes.

Confirming this, another respondent aged 57 (a woman) said:

In our tradition, male child is valued more than female child...eventhough female sometimes care more for their parents, many parents do not want to spend so much on female children at the expense of male children. It is even better for female children to generate income for their parents before they are finally married and taken away by their husbands.

Another 42-year-old man said:

I love my girls but i prefer them to work and generate income so that we can send the boys to school. This is because the boys will stay while the girls will eventually leave one after the other.

In the study area people frowned at the idea of having children out of wedlock. This may not be unconnected with the issue of property inheritance. 'Children who are considered as illegitimate are often exposed to unpleasant work conditions by their step mother or father in an effort to make them run away or simply to make them understand that they do not have any stake in the family' declared a 48 -year-old respondent. Similarly a 32-year-old woman noted:

For fear of illegitimate children inheriting any property they are exploited by family members who give them away as housemaid... Oftentimes these children are forced to engage in energy-sapping economic activities far beyond their capabilities.

The belief that hard work is a virtue encourages the practice of child labour. For the Ibibio, one must definitely have a master or mistress in life, from whom one acquires wisdom and borrows knowledge and skills. Parents are eager to engage children in strenuous task with the excuse that they are equipping them for the future. 'Allowing a child to stay idle is perceived as spoiling the child' reported a 51-year-old man. Also, a 39year-old woman has this to say 'Children must learn early in life to work hard or they will become lazy as they grow up'. Similarly, a participant who identified himself as a 48-year-old father of six children noted:

We believe strongly in working hard...We cannot afford to pamper our children, therefore instilling laziness into them. Let them know that the world is not for the weak but the strong. They must start early in life to face challenges.

\section{Discussion And Conclusion}

Arising from the discussions with the participants or respondents, the study uncovered that they possess vague understanding of child labour but are constrained by utilitarian value from discontinuing with such practice. For instance, some of the respondents posited that even though they are conspicuously aware that child labour is detrimental to the overall wellbeing of a child as well as being condemned by the government, they could do little or nothing to stop it as the need to survive becomes more urgent and pressing. The traditional 
belief that children are sources of wealth is so rife, especially among poor parents who consider themselves unfortunate for not having children that they can call their own. Some participants even anchored their perceived misfortune on the non-availability of children, stressing that their conditions would have improved if only they had children they would have engaged in the daily tasks of meeting basic family needs. This notion of the child places it on the threshold of exploitation as the child is being subjected to a plethora of activities that are inimical to his/her overall wellbeing.

Education, it was gathered has little or no impact in mediating child labour as the gap between the educated and non-educated on the issue of child labour is not so distinct. It was surprising to uncover that even among participants who had acquired education up to the tertiary level, superstitious beliefs still hold sway. Many families have failed to pay adequate attention to the female child because of the belief that she will get married one day and move to her husband's house. The female child is even denied education in favour of her male counterpart because the former is still considered a liability to the family. While at home she is exposed to all manner of menial jobs, some of which are far beyond her age and ability. In other instances, the female child is given out as housemaid in return for monthly salary which is paid to her parents or guardians.

The study was carried out in Akwa Ibom State and therefore could not be exhaustive and representative of the entire polity called Nigeria. However, it establishes the connection between tradition and perception of child labour. It emphasizes that any meaningful effort to deal with child labour should not be devoid of the traditional perception of the people. These variables are critical as they not only explore the respondents' attitudes toward child labour but equally provide deep insight into possible ways of managing the menace. However, in the research poverty was portrayed as an important negotiating factor influencing traditional perception of child labour. Beliefs supporting child labour are strengthened by poverty itself, as people explore ways of coping with the problem within the context of their cultures. This unfortunately portrayed the child as a means to an end. In Akwa Ibom State, as in other parts of Nigeria, poverty is a major concern. Conscious efforts to tackle poverty must be vigorously pursued to alleviate the suffering of people, especially those residing in rural areas. These involve the provision of credit facilities with little or no interest to encourage participation in meaningful socio-economic activities, and making available to the people basic infrastructures. The introduction of free and compulsory education by the Akwa Ibom State government is a step in the right direction because, apart from reducing the financial burden of schooling on parents, they are compelled to send their wards to school. Furthermore there is need to sensitize the population on the negative implication of child abuse, making them understand that the long term effects of child labour far outweigh any immediate benefits.

\section{References}

[1]. Aderinto,A. A. (2000), 'Social Correlates and Coping measures of Street children: A Comparative study of street and non-street children in Southwestern Nigeria' Child Abuse and Neglect. 24(9): 1199-1213

[2]. Andvig, J. C. (2001), Family-Controlled Child Labor in Sub-Saharan Africa A Survey of Research. Social Protection Discussion Paper Series No. 0122, Social Protection Unit, Human Development Network, The World Bank

[3]. Baland, Jean-Marie and Robinson, J. A. (2000) 'Is Child Labor Inefficient?' Journal of Political Economy. 108(4); 663 -679.

[4]. Bass, L. E. (2004), Child Labour in Sub-Saharan Africa: Lynne Rienner Publishers

[5]. Basu, K. and Van, P. H. (1998). The economics of child labor. The American Economic, Review, 88(3), 412-427

[6]. Bhalotra, S. and Heady, C. (1998), "Child Labor in Rural Pakistan and Ghana: Myths and Data." Working Paper. Department of Economics, University of Bristol, UK.

[7]. Canagarajah, S. and Coulombe, H. (1998), "Child Labor and Schooling in Ghana."

[8]. Policy Research Working Paper no. 1844. The World Bank: Washington D.C.Clark, C. I. D. and Sumaima, Y. (2012). Child Street Trading as an aspect of child abuse and neglect in Oredo Municipality of Edo State, Nigeria as a case study European Scientific Journal, 8(5), 148-157.

[9]. International Labour Organization (1995), Child Labor Surveys: Results of Methodological Experiments in four countries, 1992-3, Geneva: ILO International Labour Organization (2006) International Programme on the limination of Child Labour (IPEC), and Statistical Information and Monitoring Programme on Child Labour (SIMPOC). Global Child Labour Trends: 2000 to 2004, Geneva ILO, IPEC and SIMPOC Lopez- Calva, L. F. (2001), 'Child Labor; Myths, Theories and Facts' Journal of International Affairs, 55(1): 59-73

[10]. Mitullah, W. V. (2004). A review of street trade in Africa: working draft. A review Commissioned by Women in Informal Employment Globalizing and Organising (WIEGO), Kennedy School of Government, Harvard niversity, USA.

[11]. Oloko, B. A. (1990). Evolution for the Prevention of Child Labour and for working Children. International Child Labour Seminar, Amsterdam, 28(31).

[12]. Ottong, J. G., Asuquo, E. E. J., Duke, F. and Olaniran, N. S. (1994), Socio-cultural Beliefs and Maternal mortality in South Eastern Nigeria: Findings from the Study of Obstetric Haemorrage in Calabar. In Abasiekong, E. M. and Modo, I. V. O. (eds) High Points in Development, Uyo; Dorand Publishers.

[13]. Singh, A. N. (1999), 'Problems confronting Child ragpickers in Slums', The Indian Journal of Social Work, 60(2): 260-270

[14]. Udry, C. (2003) Child Labor, Center Discussion Paper No.856 Economic Growth Center Yale University UNICEF (United Nations Children's Fund). (1991), The state of the world's children1991. Oxford: Oxford University Press.

[15]. Weiner, M. (1991), 'Suffer the children.' Far Eastern Economic Review, Feb. 7, pp 26-7 